\title{
HUBUNGAN EFIKASI DIRI DENGAN KUALITAS HIDUP PASIEN PENYAKIT PARU OBSTRUKTIF KRONIS
}

\author{
I Ketut Suardana*, Ni Kadek Anita Rismawati, I Made Mertha \\ Jurusan Keperawatan Politeknik Kesehatan Denpasar \\ Jln. P. Moyo 33A, Denpasar, 80222, Bali Indonesia \\ *) E-mail: suarscorpio@gmail.com
}

\begin{abstract}
ABSTRAK
Tujuan: Penelitian ini bertujuan untuk mengetahui hubungan antara efikasi diri dengan kualitas hidup pada pasien penyakit paru obstruksi kronis di RSUD Mangusada Badung. Metode: Penelitian ini merupakan penelitian korelasional dengan menggunakan pendekatan cross sectional. Jumlah sampel sebanyak 31 orang pasien yang didiagnosis PPOK. Data dikumpulkan bulan Maret sampai dengan April 2017 menggunakan kuesioner The COPD Self Efficacy Scale (CSES) dari Wigal (1991) dan kuesioner kulitas hidup dari WHOQOL (2004). Data dianalisis dengan secara univariat dan bivariat. Hasil penelitian: Efikasi diri pasien PPOK di RSUD Mangusada Badung diperoleh hasil terbanyak dengan kategori kurang yaitu 18 orang (58,1\%). Kualitas hidup pasien PPOK di RSUD Mangusada Badung diperoleh hasil terbanyak dengan kategori kurang yaitu 17 orang (54,8\%). Hasil analisis dengan Spearman Ranks diperoleh nilai (p) yaitu 0,001 $(<\boldsymbol{\alpha} 0,05)$ dengan nilai $\mathrm{r}=0,649$. Ada hubungan yang bermakna dengan kekuatan kuat antara efikasi diri dengan kualitas hidup. Semakin baik efikasi diri maka semakin tinggi kualitas hidup pasien PPOK. Kesimpulan: kualitas hidup pasien PPOK bisa ditingkatkan dengan meningkatkan efikasi diri.
\end{abstract}

Kata Kunci: efikasi diri, kualitas hidup, PPOK

\section{The Relationship of Self Efficacy to Quality of Life in Patients With Chronic Obstructive Pulmonary Disease (COPD)}

\section{ABSTRACT}

Objective: This study aim to describe the relationship of self efficacy to quality of life in patients with chronic obstructive pulmonary disease (COPD) in Mangusada Hospital Badung Regency area. Methods: The study applied correlational study using cross sectional approach. There were thirty one patients. Data was colected on March until April 2017 with using questionnaire of The COPD Self Efficacy Scale (CSES) from Wigal (1991) and questionnaire of quality of life from WHOQOL (2004). Data was analysed with using univariate and bivariate analyses. Results: The results of this study showed that self efficacy of patient with COPD were mostly in the less category, which was eighteen patients (58.1\%). Quality of life in patient with COPD were mostly in less category, which was seventeen patients (54.8\%). The result of Spearman Rank test showed that p-value $=0.001(<\alpha 0.05)$ with $r=0,649$. There is a significant relationship with the strong power between self-efficacy and quality of life. The better self-efficacy the higher quality of life patient with COPD. Conclusion: quality of life patient with COPD could be improved by increasing self-efficacy.

Keywords: Self efficacy, quality of life, chronic obstructive pulmonary disease 


\section{LATAR BELAKANG}

Penyakit Paru Obstruksi Kronik (PPOK) adalah penyakit paru kronik yang ditandai dengan keterbatasan aliran udara didalam saluran napas yang tidak sepenuhnya reversible dan bersifat progresif (Depkes RI, 2008). Kondisi ini menyebabkan udara terperangkap dan menimbulkan terganggunya pertukaran gas sehingga akan muncul gejala-gejala batuk, produksi sputum meningkat dan wheezing. Menurut data Badan Kesehatan Dunia pada tahun 1990 PPOK menempati urutan keenam sebagai penyebab utama kematian di dunia (World Health Organization, 2002).

Hasil Survei Kesehatan Rumah Tangga (SKRT) Departemen Kesehatan Republik Indonesia menunjukkan PPOK menduduki peringkat kelima sebagai penyebab kematian di Indonesia. Data Profil Kesehatan Provinsi Bali tahun 2014 didapatkan data pasien yang menderita penyakit PPOK yang menjalani rawat inap di RSUD di Provinsi Bali sebanyak 1.248 jiwa dan pasien rawat jalan dengan penyakit PPOK sebanyak 3.880 di RSUD di Provinsi Bali. Data yang didapat di RSUD Badung tahun 2013 pasien PPOK di RSUD Badung sebanyak 112 orang, tahun 2014 sebanyak 204 orang, tahun 2015 sebanyak 240 orang dan tahun 2016 pasien PPOK mencapai 392 orang.

Dengan meningkatnya kasus PPOK di Indonesia maka Pemerintah mengeluarkan Kepmenkes 1022 tahun 2008 tentang Pedoman Pengendalian Penyakit Paru Obstruktif Kronik yaitu penyuluhan (Komunikasi Informasi Edukasi), penemuan dan tatalaksana kasus (termasuk deteksi dini PPOK), surveilans epidemiologi (kasus termasuk kematian dan faktor risiko). Walaupun Pemerintah telah mengeluarkan Kepmenkes 1022 tahun 2008 namun angka kejadian PPOK di Bali tetap meningkat. Seiring dengan semakin meningkatnya kasus PPOK serta sifat penyakitnya yang kronis maka peningkatan kualitas hidup penanganan pasien PPOK tidak hanya berfokus pada memperpanjang usia dan harapan hidup tetapi kini mulai berfokus pada peningkatan kualitas hidup. Kualitas hidup merupakan kondisi status kesehatan gabungan dari dimensi diantaranya gejala, fungsi fisik, kognitif, kondisi psikososial, status emosi, persepsi, dan keyakinan terhadap kemampuan berperilaku kesehatan dan semua ini sangat menentukan kualitas hidup seseorang (Gupta \& Kant, 2009).

Kegawatdaruratan yang terjadi pada pasien dengan PPOK yaitu infeksi pada saluran nafas, terjadinya dipsnue yang menyebabkan terjadinya gawat nafas dan menyebabkan penurunan kesadaran serta gagal jantung kanan (Perhimpunan Dokter Paru Indonesia, 2011). Pengobatan dan perawatan PPOK menjadi suatu proses panjang dimana pasien memerlukan strategi untuk mengelola penyakitnya seperti menghindari faktor risiko PPOK dan mengenal gejala kegawatdaruratan PPOK.

Bandura (1997) mengemukakan teori efikasi diri didasarkan pada premis bahwa individu akan membuat penilaian tentang kapasitas mereka dalam perilaku perawatan diri untuk mencapai tujuan yang diinginkan. Persepsi efikasi diri mengacu pada keyakinan seseorang melakukan tindakan dalam menghadapi situasi tertentu (Bentsen dkk, 2010). Banyak pasien PPOK tidak mampu mengontrol penyakit dalam kehidupannya (Bentsen dkk, 2010). Kondisi batuk yang tak sembuh serta dipsnue menyebabkan keterbatasan dalam melakukan kegiatan sehari-hari pada pasien PPOK, pembatasan kegiatan sosial, tekanan keuangan.

Efikasi yang rendah menunjukkan kurangnya keyakinan pasien PPOK menghadapi kondisi penyakitnya. Hal ini menyebabkan mereka kurang antisipasi terhadap 
kegawatan yang terjadi seperti infeksi pada saluran nafas, terjadinya dipsnue yang menyebabkan terjadinya gawat nafas dan menyebabkan penurunan kesadaran serta gagal jantung kanan (Perhimpunan Dokter Paru Indonesia, 2011).

Dari hasil wawancara dengan lima pasien PPOK yang menjalani perawatan di RSUD Mangusada menunjukkan bahwa dampak dari PPOK yang dideritanya mempengaruhi banyak aspek diantaranya berhenti bekerja, malu keluar rumah karena batuk yang dideritanya, tidak mampu melakukan aktifitas sehari-hari dan tidak yakin dengan kemampuannya melakukan perawatan pada dirinya sendiri. Berdasarkan uraian di atas, maka sangat penting untuk mengetahui lebih lanjut mengenai hubungan antara efikasi diri dengan kualitas hidup pada pasien Penyakit Paru Obstruktif Kronis (PPOK).

\section{METODE}

Penelitian ini merupakan penelitian korelasional dengan menggunakan pendekatan cross sectional. Penelitian ini dilakukan di Ruang Oleg RSUD Mangusada Badung selama 1 bulan yaitu bulan MaretApril 2017. Sampel sebanyak 31 orang pasien yang didiagnosis PPOK. Minimal menderita PPOK >1 bulan, kesadaran compos mentis, dapat berkomunikasi dengan baik yang dipilih dengan purposive sampling.

Data efikasi diri diukur dengan menggunakan kuesioner The COPD Self Efficacy Scale (CSES) oleh Fast dkk (2010) yang diinformasikan di Essays, UK (2018) tetapi tidak dilakukan uji validitas dan reliabilitas. Kuesioner kualitas hidup diukur menggunakan kuesioner kualitas hidup dari The World Health Organization Quality of Life (WHOQOL)-BREF (2004), terdiri dari 30 pertanyaan dengan nilai validitasnya 0,36 dan reliabilitas adalah dengan Cronbach alpha 0,956. Hasil pengisian kuesioner kualitas hidup dan efikasi diri diolah dengan komputer dan hasilnya diklasifikasikan menjadi baik jika skor $76-100 \%$, cukup jika skor $56-75 \%$ dan kurang jika $\leq 55$. Data dianalisis secara univariate dan bivariat. Sebelum pengambilan data penelitian, peneliti telah memperoleh hasil uji kelayakan etik di Poltekkes Denpasar Nomor LB.02.03/ EA/KEPK/0203.1/2017.

\section{HASIL}

Karakteristik responden disajikan di tabel 1.

Tabel 1. Distribusi Frekuensi Pasien

PPOK Berdasarkan Jenis Kelamin, usia, lama Pekerjaan, menderita PPOK, riwayat merokok, dan tingkat pendidikan $(n=31)$

\begin{tabular}{lcc}
\hline \multicolumn{1}{c}{ Karakteristik } & f & $\%$ \\
\hline Jenis Kelamin & & \\
a. Laki-laki & 22 & 71 \\
b. Perempuan & 9 & 29 \\
\hline Usia & & \\
a. $<50$ tahun & 0 & 0 \\
b. $50-60$ tahun & 10 & 32,3 \\
c. $>60$ tahun & 21 & 67,7 \\
\hline Pekerjaan & & \\
a. Tidak bekerja & 20 & 64,5 \\
b. Petani/Buruh & 5 & 16,1 \\
c. Wiraswasta & 6 & 19,4 \\
\hline Lama Menderita PPOK & & \\
a. $\leq 1$ tahun & 13 & 41,9 \\
b. >1 tahun & 18 & 58,1 \\
\hline Riwayat Merokok & & \\
a. Merokok & 19 & 61,3 \\
b. Tidak merokok & 12 & 38,7 \\
\hline
\end{tabular}




\begin{tabular}{lcc}
\hline \multicolumn{1}{c}{ Karakteristik } & f & $\%$ \\
\hline Tingkat Pendidikan & & \\
a. Tidak sekolah & 9 & 29 \\
b. SD & 15 & 48,4 \\
c. SMP & 5 & 16,1 \\
d. SMA & 2 & 6,5 \\
\hline
\end{tabular}

Berdasarkan tabel 1, terlihat pasien PPOK di RSUD Mangusada Badung sebagian besar laki-laki, mayoritas mengenai usia di atas 60 tahun $(67,7 \%)$. Responden yang menderita PPOK lebih banyak pada responden yang tidak bekerja sebanyak 20 orang $(64,5 \%)$, lama responden menderita PPOK sebagian besar lebih dari 1 tahun yaitu sebanyak 18 orang $(58,1 \%)$, kebanyakan mempunyai riwayat merokok sebanyak 19 orang $(61,3 \%)$, dan paling banyak terjadi pada responden yang berpendidikan SD..

Tabel 2. Distribusi Frekuensi Efikasi Diri dan Kualitas Hidup Pasien PPOK di RSUD Mangusada Bandung tahun 2017 $(n=31)$

\begin{tabular}{lcc}
\hline \multicolumn{1}{c}{ Variabel } & $\mathbf{f}$ & $\%$ \\
\hline Efikasi Diri & & \\
a. Baik & 1 & 3,2 \\
b. Cukup & 12 & 41,9 \\
c. Kurang & 18 & 58,1 \\
Kualitas hidup: & & \\
a. Baik & 2 & 6,5 \\
b. Cukup & 12 & 38,7 \\
c. Kurang & 17 & 54,8 \\
\hline
\end{tabular}

Berdasarkan tabel 2 terlihat bahwa sebagian besar subyek penelitian memiliki efikasi diri kurang yaitu sebanyak 18 orang $(58,1 \%)$. Berdasarkan tabel tersebut terlihat bahwa setengah dari subyek penelitian memiliki kualitas hidup kurang yaitu 54,8\%.

Hubungan Efikasi Diri dengan Kualitas Hidup Pasien PPOK ditunjukkan di Tabel 3.

\begin{tabular}{|c|c|c|}
\hline Variabel & Nilai $r$ & Nilai $p$ \\
\hline $\begin{array}{l}\text { Efikasi Diri } \\
\text { Kualitas Hidup }\end{array}$ & 0,649 & 0,001 \\
\hline
\end{tabular}

Berdasarkan hasil analisis data menggunakan uji Spearman Rho pada tabel diperoleh nilai signifikansi $(p)$ yaitu 0,001 yang dibandingkan dengan a yaitu 0,05 dimana nilai $p<0,05$ (Tabel 3 ) sehingga Ha diterima artinya ada hubungan yang signifikan antara efikasi diri dengan kualitas hidup pasien PPOK di RSUD Mangusada Badung. Jika dilihat nilai koefisien pada tabel di atas didapatkan hasil nilai koefisien korelasi $(r)$ yaitu 0,649 dengan arah positif maka disimpulkan ada hubungan yang kuat antara efikasi diri dengan kualitas hidup. Semakin tinggi efikasi diri semakin baik kualitas hidup pasien PPOK di RSUD Mangusada Badung.

\section{DISKUSI}

Berdasarkan hasil penelitian terlihat pasien PPOK di RSUD Mangusada Badung sebanyak $71 \%$ (lebih dominan) mengenai laki-laki dibandingkan perempuan. Kecenderungan laki-laki terjangkit PPOK dilatarbelakangi oleh riwayat merokok yang lebih banyak dilakukan lakilaki dibandingkan perempuan. Hal ini didukung data kebanyakan responden mempunyai riwayat merokok $(61,3 \%)$. Konsumsi rokok yang mengandung TAR dan nikotin menyebabkan plaque pada sistem pernafasan bagian bawah yang dapat menimbulkan elastisitas paru berkurang dan ekspirasi bertambah berat. 
Sebagian besar penderita PPOK mengenai usia di atas 60 tahun $(67,7 \%)$. Pada usia lanjut terjadi penurunan anatomi dan fisiologi sistem pernafasan dimana kemampuan paru melakukan ekpansi mulai berkurang. Responden yang menderita PPOK lebih banyak pada responden yang tidak bekerja sebanyak 20 orang $(64,5 \%)$, lama responden menderita PPOK sebagian besar lebih dari 1 tahun yaitu sebanyak 18 orang $(58,1 \%)$, dan paling banyak terjadi pada responden yang berpendidikan SD dan tidak sekolah. Karakteristik tersebut di atas memberi kontribusi risiko menurunnya kemampuan untuk mengenal penyakitnya sehingga upaya mempertahankan dan meningkatkan kualitas hidup sehingga mengakibatkan timbulnya kualitas hidup yang rendah.

Analisis hubungan efikasi diri dengan kualitas hidup menunjukkan bahwa ada hubungan yang kuat antara efikasi diri dengan kualitas hidup. Hasil penelitian ini sesuai dengan penelitian yang dilakukan Benstsen, dkk (2010) yang menyebutkan bahwa seseorang dengan efikasi diri baik akan menunjukkan kualitas hidup baik dalam pengelolaan penyakitnya. Penelitian lain dilakukan oleh Kara (2005) menyebutkan efikasi diri mempunyai hubungan positif dengan perilaku perawatan diri yang nantinya akan berpengaruh pada kualitas hidup pasien .

Kemampuan pasien mengenal masalah kesehatan dan mencari solusi dalam mengatasinya membuat pasien lebih waspada dan cepat mengantisipasi permasalahan. Pengenalan dini tanda dan gejala kekambuhan penyakit menyebabkan pasien lebih percaya diri menjalankan kehidupan yang ditandai dengan pasien dapat istirahat yang cukup, tidak panik apabila rasa sesak kembali muncul dan tidak bosan menjalankan program terapi.
Berdasarkan hasil studi pendahuluan sebagian besar responden menyatakan kurang puas akan kondisi kesehatan fisiknya yang berhubungan dengan kebutuhan tidur serta aktivitas sehari-hari karena sesak yang dirasakan. Berdasarkan hasil penelitian juga terlihat bahwa lebih dari setengah subyek penelitian memiliki efikasi diri kurang yaitu sebanyak 18 orang $(58,1 \%)$.

Berdasarkan hasil studi pendahuluan yang dilakukan bahwa dampak dari PPOK yang dideritanya mempengaruhi banyak aspek diantaranya berhenti bekerja, malu keluar rumah karena batuk yang dideritanya, tidak mampu melakukan aktifitas sehari-hari dan tidak yakin dengan kemampuannya melakukan perawatan pada dirinya sendiri. Ini merupakan salah satu indikator dari tingkat efikasi diri pasien dimana pasien merasa nyaman berada di sisi keluarga. Kepuasan atas dukungan yang diberikan keluarga meningkatkan interaksi antar keluarga yang menimbulkan peningkatan kualitas hidup.

Hasil penelitian ini menunjukkan bahwa lebih dari setengah responden memiliki kualitas hidup kurang. Hal tersebut dipengaruhi oleh penurunan status kesehatan pasien PPOK seperti sesak dan batuk yang dirasakan yang membuat pasien tidak dapat melakukan aktivitas sehari-hari. Untuk mengatasi penurunan kualitas hidup serta memperbaiki status kesehatan pasien maka diperlukan adanya pelayanan kesehatan langsung seperti membantu pasien batuk efektif, melakukan program terapi sebagai tindakan delegatif dan penyuluhan tentang penyakit yang dapat dilakukan oleh tenaga kesehatan untuk pasien PPOK seperti penyuluhan menghindari faktor risiko memperberat kondisi penyakitnya yaitu merokok serta pengobatan yang tidak dapat ditinggalkan (Kara, 2005). 
Peningkatan kualitas hidup sangat dipengaruhi oleh proses pengobatan yang sangat bergantung pada kerja sama antara petugas kesehatan, pasien dan keluarga. Ketersediaan pelayanan khusus konsultasi bagi pasien PPOK sangat diperlukan untuk dapat memaksimalkan pemahaman tentang permasalahan dan langkah pencegahan, penanganan serta pemulihan kondisi bagi pasien. Perawat dapat menjelaskan pentingnya latihan nafas dan batuk efektif, menjelaskan efek samping dan reaksi obat, penggunaan dosis inhaler, perawatan gigi dan mulut, serta mendiskusikan faktor lingkungan yang dapat meningkatkan kondisi pasien.

Peran perawat dalam mengkaji efikasi diri pada pasien PPOK menjadi data dasar untuk dapat menentukan asuhan keperawatan pada pasien sehingga kualitas hidup pasien tersebut dapat ditingkatkan. Peningkatan kualitas hidup pada pasien PPOK dapat dilakukan dengan peningkatan keempat komponen kualitas hidup yang meliputi kesehatan fisik, kesehatan psikologis, hubungan sosial serta lingkungan.

Pasien memerlukan efikasi diri untuk dapat meningkatan keempat komponen kualitas hidup. Semakin baik efikasi diri pasien tersebut maka pasien akan mampu dalam melakukan perawatan diri dan nantinya akan dapat meningkatkan kualitas hidupnya. Begitu juga sebaliknya apabila pasien dengan efikasi diri kurang maka tidak akan mampu dalam melakukan perawatan diri sehingga akan berpengaruh pada perburukan kondisi dan penurunan kualitas hidupnya. Peningkatan kualitas hidup pasien PPOK dapat dilakukan dengan meningkatkan keempat komponen kualitas hidup yang meliputi kesehatan fisik, kesehatan psikologis, hubungan sosial, dan lingkungan.

Setiap komponen kualitas hidup tersebut saling berhubungan antara satu dengan yang lainnya. Kesehatan fisik diperbaiki dengan melakukan pengobatan untuk mencegah komplikasi PPOK. Kesehatan psikologis dapat ditingkatkan dengan meningkatkan kesehatan fisiknya sehingga pasien memiliki gambaran tubuh yang baik serta memberikan informasi dan pendidikan kesehatan terkait penyakitnya untuk mengurangi perasaan negatif yang sering dirasakan pasien. Sedangkan untuk hubungan sosial dan lingkungannya, pasien PPOK harus mampu meningkatkan prilaku kesehatannya sehingga memperoleh dukungan sosial yang baik.

Untuk meningkatkan prilaku kesehatan maka diperlukan lingkungan yang mendukung dimana pasien mudah mengakses informasi dan ketersedian pelayanan kesehatan dan tenaga kesehatan yang mampu menunjang peningkatan status kesehatan. Apabila pasien PPOK dapat meningkatkan dan menyeimbangkan keempat domain tersebut maka pasien PPOK akan memiliki kualitas hidup yang baik (Skevington, Lotfy, \& O'Connell, 2004).

Hasil penelitian menunjukan bahwa kualitas hidup pasien PPOK sebagian besar kurang, namun diperoleh juga responden yang memiliki kualitas hidup baik. Hal tersebut dipengaruhi oleh penurunan status kesehatan pasien PPOK secara umum. Penurunan status kesehatan pasien dipengaruhi oleh ketidakmampuan pasien melakukan program pengobatannya dengan baik.

Untuk mengatasi penurunan kualitas hidup dan memperbaiki kesehatan pasien maka diperlukan penyuluhan untuk pasien PPOK. Penyuluhan diperlukan karena PPOK adalah penyakit yang berhubungan dengan gaya hidup, pengenalan tentang kondisi kesehatan fisik dan pengobatan yang tidak dapat ditinggalkan. Peningkatan kualitas hidup sangat dipengaruhi oleh faktor pengobatan yang sangat bergantung 
pada kerjasama antar petugas pelayanan kesehatan dengan penderita PPOK serta keluarganya.

Pengobatan dan perawatan PPOK menjadi suatu proses panjang dimana pasien memerlukan strategi untuk mengelola penyakitnya seperti menghindari faktor risiko PPOK dan mengenal gejala kegawatdaruratan PPOK. Dengan pengenalan tanda dini kelainan dan kegawatdaruratan serta mengendalikan kondisi penyakitnya, maka pasien akan dapat meningkatkan kualitas hidupnya.

Keterbatasan penelitian ini adalah kuesioner The COPD Self Efficacy Scale (CSES) oleh Fast (2015) tidak dilakukan uji validitas dan reliabilitas lagi.

\section{SIMPULAN}

Berdasarkan tujuan khusus penelitian ini dapat disimpulkan beberapa hal sebagai berikut: karakteristik responden di RSUD Mangusada Badung sebagian besar berusia lebih dari 60 tahun yaitu sebanyak $67,7 \%$ dan berjenis kelamin laki-laki sebesar $71 \%$ dengan tingkat pendidikan terbanyak yaitu SD sebanyak $48,4 \%$, lebih dari setengah responden tidak bekerja $(64,5 \%)$. Sebagian besar responden memiliki riwayat merokok sebesar $61,3 \%$ serta lama menderita PPOK setengahnya lebih dari 1 tahun yaitu 58,1\%. Efikasi diri pasien PPOK di RSUD Mangusada Badung diperoleh hasil terbanyak dengan kategori kurang sebanyak 18 orang $(58,1 \%)$ serta Kualitas hidup pasien PPOK di RSUD Mangusada Badung diperoleh hasil terbanyak dengan kategori kurang sebanyak 17 orang $(54,8 \%)$. Hasil uji Spearman Ranks dengan a yaitu 0,05 menunjukkan ada hubungan yang kuat antara efikasi diri dengan kualitas hidup pasien PPOK di RSUD Mangusada Badung dengan nilai $(p)$ yaitu 0,001 dan nilai koefisien korelasi ( $r$ ) yaitu 0,649.

\section{DAFTAR PUSTAKA}

Bandura, A. (1997). Self-efficacy: The exercise of control. New York: Freeman.

Bentsen SB, Wentzel-Larsen T, Henriksen AH, Rokne B, Wahl AK. Self-efficacy as a predictor of improvement in health status and overall quality of life in pulmonary rehabilitation an exploratory study. Patient Educ Couns, 81(1).

Depkes RI (2008). Pedoman pengendalian Penyakit Paru Obstruktif Kronis (PPOK). Jakarta: Direktorat Jenderal pengendalian dan Penyehatan Lingkungan Direktorat Pengendalian Penyakit Menular.

Essays, UK. Retrieved from https://www. ukessays.com/essays/psychology/ difference-between-self-confidenceand-self-efficacy-psychology-essay. php.

Gupta, B \& Kant. (2009). Health Related Quality of Life in COPD. The Internet Jurnal Of Pulmonary Medicine. Retrieved from http://www.ispub. com/journal/the_internet_journal_ of_pulmonary_medicine/

Kara, M. (2005). Preparing nurses for the global pandemic of chronic obstructive pulmonary desease. Journal of Nursing Scholarship. Retrieved from https://sigmapubs.onlinelibrary. wiley.com/doi/abs/10.1111/j.15475069.2005.00024.x Diperoleh tanggal 25 November 2016

Keputusan Menteri Kesehatan Republik Indonesia Nomor 1022/MENKES/ SK/XI/2008 tentang Pedoman Pengendalian Penyakit Paru Obstruktif Kronik. Retrieved from http://www.pdpersi.co.id/peraturan/ kepmenkes/kmk10222008.pdf

Perhimpunan Dokter Paru Indonesia (2011). Penyakit Paru Obstruktif 
Kronik (PPOK) Diagnosis dan Penatalaksanaan. Jakarta: PDPI.

Skevington, S. M., Lotfy, M \& O'Connell, K. A. (2004). The World Health Organization's WHOQOL-BREF Quality of Life Assesment. Psychometric Property and Result of The International Field Trial a Report from The WHOQOL Group: 299-307.
The World Health Organization Quality of Life (WHOQOL)-BREF. Retrieved from https://www.who.int/substance_abuse/research_tools/en/ english_whoqol.pdf.

WHO. (2002). International Statistical Classification of Diseases and Related Health Problem (ICD-10). Geneva: WHO. 